\title{
DETERMINING THE PROFIT MAXIMIZATION LEVEL: AN EMPIRICAL INVESTIGATION IN NAVANA FURNITURE, BANGLADESH
}

\author{
Md. Mahadi Hasan \\ Lecturer in Finance, \\ Green University of Bangladesh (GUB) \\ Nour Mohammed Chowdhury \\ Lecturer in Finance \\ Green University of Bangladesh (GUB) \\ Md. Mahmudul Alam \\ Postgraduate student \\ Institute for Environment and Development (LESTARI) \\ National University of Malaysia (UKM)
}

\section{Citation Reference:}

Hasan, M.M., Chowdhury, N.M., and Alam, M.M. 2010. Determining the Profit Maximization Point: An Empirical Investigation for Navana Furniture, Bangladesh, Green University Review, Vol. 1(2). pp. 81-87. (ISSN 2218-5283; Publisher- Green University of Bangladesh)

This is a pre-publication copy.

The published article is copyrighted by the publisher of the journal. 


\title{
DETERMINING THE PROFIT MAXIMIZATION LEVEL: AN EMPIRICAL INVESTIGATION IN NAVANA FURNITURE, BANGLADESH
}

\author{
Md. Mahadi Hasan ${ }^{1}$ \\ Nour Mohammed Chowdhury ${ }^{2}$ \\ Md. Mahmudul Alam ${ }^{3}$
}

\begin{abstract}
Business always tries to find ways to improve its competitiveness and gain maximum profit. Organizations easily determine the maximum production and profit level through the simplex method in linear programming. This paper examined the profit maximization point for dining chair and sofa manufacturing by Navana Furniture Company, Bangladesh through simplex method in linear programming and graphical method. The findings showed that Navana Furniture Company can improve its profit by $4.03 \%$ for dining chair and sofa manufacturing cases if it follows the new profit maximizing point that is determined by this study. The findings of the paper will be helpful for the company management, shareholders as well as other companies to improve their performance.
\end{abstract}

Key words: Profit maximization, linear programming, simplex method, point testing, Navana Furniture.

\section{INTRODUCTION}

In the competitive market, companies are striving for ways to achieve competitive advantages as well as maximizing their profits. Profit maximization is a process by which a company determines the price and output level that provides maximum profit. So, determining the profit maximization point is very crucial, especially for manufacturing company.

Linear programming is a most efficient tool to determine profit maximization level. Its history dates back from 1940s. Main motivation for the need of linear programming goes back to the war time when it was necessary to solve many complex planning problems. The simplex method which is used to solve linear programming was developed by George B. Dantzig in 1947, and has been keeping pace ever since with the extraordinary growth of computing power. Linear programming can be applied to various fields of study. It is used most extensively in business and economics, but can also be utilized for some engineering problems. Applications can be found in many different industries such as airline scheduling, shipping of telecommunication networks, oil refining and blending, stock and bond portfolio selection etc. It can handle hundreds of variables. So, it has proved useful in modeling diverse types of problems in planning, routing, scheduling, assignment, and design.

This paper provides a mathematical framework to understand the performance and argues how simplex method helps a company to achieve competitiveness and success. To determine the profit maximizing level of an entity, this study focuses on the Navana Furniture Company, Bangladesh. Navana Furniture is leading company manufacturing branded furniture by a sister unit of Aftab Automobile Ltd. It was established in 2002. Navana furniture is featured by the attributes of aesthetic design and prototype, material selection and molding through testing, assembling and distribution. Abreast of being a strong leading player in the market, all their -produced furniture are guaranteed by stringent quality and standards. The company offers a wide product range that can be tailored for customer requirement and most suitable for modern offices.

\section{METHODOLOGY}

\footnotetext{
${ }^{1}$ Lecturer in Finance, Green University of Bangladesh (GUB)

${ }^{2}$ Lecturer in Mathematics, World University of Bangladesh (WUB)

${ }^{3}$ Postgraduate student, Institute for Environment and Development (LESTARI), National University of Malaysia (UKM)
} 


\section{Data Collection}

The required data have been collected through structured questionnaire interview. Sample size was 40 of which 5 were executives and 35 were workers. Some assumptions were made through direct observations. Some pre-arranged secondary data were also used for the study. Both descriptive and inferential statistics have been used in the analysis. For experimental evaluation, MATLAB 7.0 and $\mathrm{C}++$ software were applied.

\section{Data Analysis}

Variables and Models: Among several products produced by Navana Furniture Company of Bangladesh, this study focuses only on dining chairs and sofas, because the company uses wood only for these two products and rest are made by laminated board. This firm measures wood by cubic feet, where dining chair needs 1.2 cubic feet of wood, and sofa needs 0.97 cubic feet of wood. Each dining chair takes twelve hours of labor from both the carpentry department and from the finishing department. Each sofa requires fourteen hours by both carpentry and finishing. The market price of dining chair and sofa are Tk 5,690 and Tk 6,590 respectively. This firm's profit from these two products is $40 \%$. So, profit from per unit of dining chair profit is Tk 2,276 and per unit of sofa profit is $\mathrm{Tk} 2,636$.

Flash of the Requirements: The study considers 220 man-hours as standard working hours of the company in a week. For manufacturing the product the company uses 20 cubic feet raw materials (wood) per week. Requirements for manufacturing dining chair and sofa by Navana Furniture Company, Bangladesh are given in table1.

Table1: Requirements for manufacturing dining chair and sofa by Navana Furniture Company

\begin{tabular}{cccc}
\hline Resources & Dining Chair & Sofa & Constraint \\
\hline Wood (cft) & 1.2 & 0.97 & 20 \\
Labor (hours) & 12 & 14 & 220 \\
\hline Unit profit (TK) & 2,276 & 2,636 & \\
\hline
\end{tabular}

Source: Primary Data Collection 2009

Design of LP Model: To get an optimum point by using a linear programming, the objective function is to be maximized and all the constraints are "less-than-or-equal-to" inequalities. Based on the above mentioned data, the objective function $(\mathrm{Eq} 1)$ and the constraint equations $(\mathrm{Eq} 2,3)$ are:

$$
\begin{aligned}
& \mathrm{p}=2,276 \mathrm{x}+2,636 \mathrm{y} \\
& 1.2 \mathrm{x}+.97 \mathrm{y} \leq 20 \\
& 12 \mathrm{x}+14 \mathrm{y} \leq 220 \\
& \text { Where, } \mathrm{x}>=0, \mathrm{y}>=0 ; \mathrm{p}=\text { profit; } \mathrm{x}=\text { dining chair; } \mathrm{y}=\text { sofa }
\end{aligned}
$$

Slack variables used in the analysis are $S_{\mathrm{W}}$ and $\mathrm{S}_{\mathrm{L}}$ in the Eq 2 and Eq 3. These are called slack because of the difference between the amount of resource available (20 and 220) and the amount used $(1.2 x+0.97 y$ and $12 x+14 y)$.

$$
\begin{aligned}
& 1.2 x+0.97 y+S_{W}=20 \ldots \\
& 12 x+14 y+S_{L}=220 \\
& \text { Where, } S_{W} \geq 0 \text { and } S_{L} \geq 0
\end{aligned}
$$

\section{RESULTS AND DISCUSSIONS}

The profit of furniture manufacturing depends on the usage of types of raw materials including the labor (hour). The estimate of main raw materials and labor hours used for manufacturing the products in a month depict in table 2. 
Table 2: Product item wise requirements for manufacturing dining chair and sofa by Navana Furniture Company

\begin{tabular}{|c|c|c|c|c|c|c|}
\hline $\begin{array}{l}\text { Name of } \\
\text { Items }\end{array}$ & Model No. & $\begin{array}{c}\text { Main Raw } \\
\text { Materials }\end{array}$ & $\begin{array}{c}\text { Time per } \\
\text { unit } \\
\text { (in hour) }\end{array}$ & $\begin{array}{l}\text { Monthly } \\
\text { Quantity }\end{array}$ & $\begin{array}{c}\text { Total } \\
\text { Time } \\
\text { (in hour) }\end{array}$ & $\begin{array}{c}\text { Price } \\
\text { (Tk per } \\
\text { unit) } \\
\end{array}$ \\
\hline \multirow{2}{*}{$\begin{array}{c}\text { Computer } \\
\text { Table }\end{array}$} & TEL0427 & $39.05 *$ & 3 & 40 & 6 & 6890 \\
\hline & TCC0601 & $27.81 *$ & 4 & 100 & 15 & 5290 \\
\hline \multirow{2}{*}{$\begin{array}{l}\text { Dining } \\
\text { Chair }\end{array}$} & CDH6101 & $1.2^{\wedge}$ & 12 & 60 & 96 & 6990 \\
\hline & CDH6102 & $1.2^{\wedge}$ & 12 & 60 & 96 & 5690 \\
\hline \multirow{2}{*}{ Bed } & HBD0816 & $69.51 *$ & 4 & 20 & 10 & 15900 \\
\hline & HBD0811 & $68.2 *$ & 3 & 15 & 10 & 14990 \\
\hline \multirow{2}{*}{ Cupboard } & HKB0870 & $96.47 *$ & 6 & 30 & 12 & 13990 \\
\hline & НКВ0879 & $84.03 *$ & 5 & 50 & 14 & 11690 \\
\hline \multirow{2}{*}{ Sofa } & SSH6150 & $0.97^{\wedge}$ & 14 & 20 & 124 & 6590 \\
\hline & SSH6151 & $0.97^{\wedge}$ & 14 & 25 & 124 & 7390 \\
\hline \multirow{2}{*}{ Bookshelf } & KSM0770 & $77.18 *$ & 4 & 70 & 9 & 8990 \\
\hline & KSM0771 & $57.27 *$ & 3 & 60 & 8 & 7050 \\
\hline
\end{tabular}

* Made by laminated board and measured by square feet

$\wedge$ Made by wood and measured by cubic feet

Source: Primary Data Collection 2009

The linear programming provides one positive and one negative point to solve equation. As price cannot be negative, the positive point is the appropriate point for objective equation (Eq 1). In the graphical presentation (Figure 1) of the (Eq 2,3), the feasible region is shaded (it includes the edges in this case). The maximum (minimum) value of the objective function occurs at one of the vertices of the feasible region. Here, the vertices are at $(0,15.71),(12.9,4.7)$ and $(16.7,0)$.

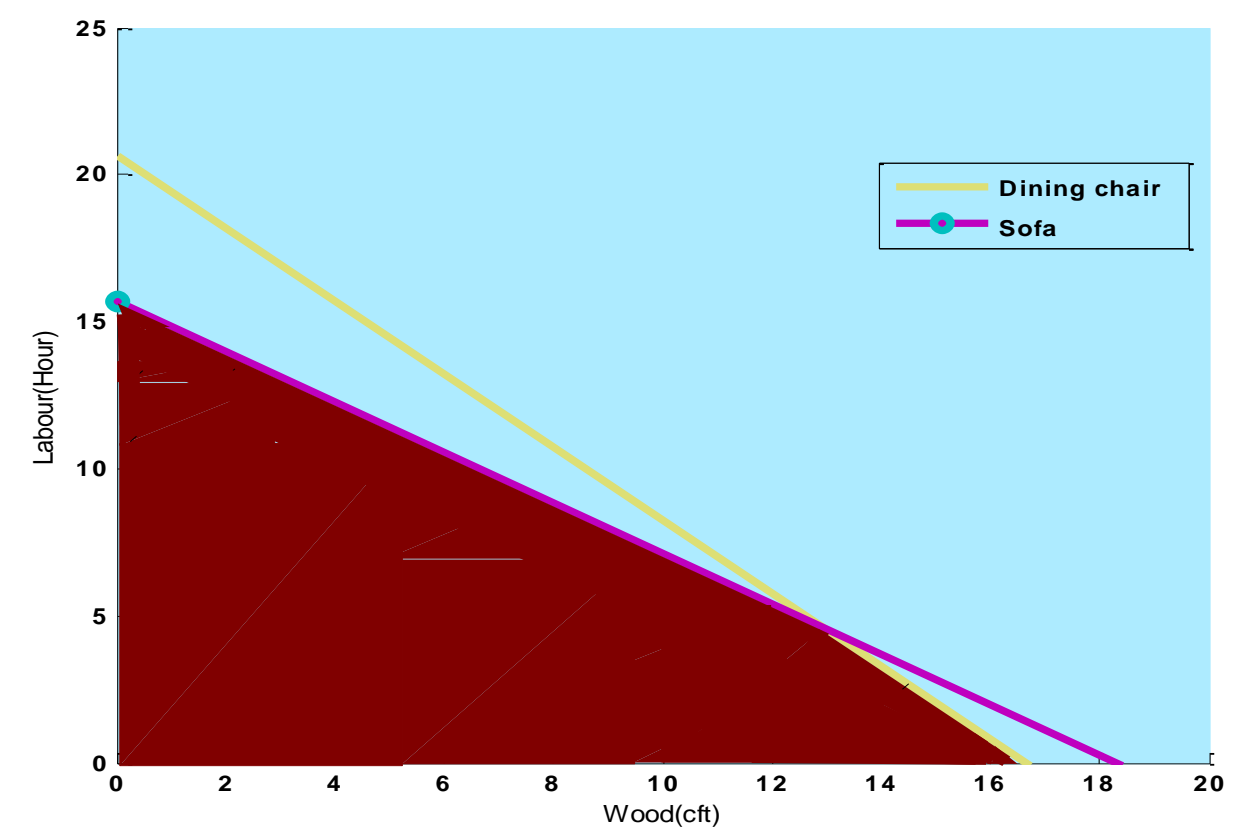

Figure 1: Profit Maximizing point (Interaction Point) Source: Primary Data Collection 2010

By the point testing using the vertex method, the output for Eq. 1 will be,

$$
\text { At }(0,15.71), p=0+41,411.56=41,411.56
$$




$$
\begin{aligned}
& \text { At }(12.9,4.7), p=29,360+12,389.2=41,749.2 \\
& \text { At }(16.7,0), p=38,009.2+0=38,009.2
\end{aligned}
$$

So, maximum profit will be at the point of 12.9 unit dining chairs and 4.7 unit sofas. However, based on the given raw materials of 20 cubic feet wood and 220 man-hour at 12 man-hour for each dining chair and 14 man-hour for each sofa, the firm currently manufactures 13 dining chairs and 4 sofas. Therefore the profit of this firm is,

$$
\begin{aligned}
& p=2,276 x+2,636 y \\
& p=2,276^{*} 13+2,636^{*} 4 \\
& p=\text { TK } 40,132
\end{aligned}
$$

Consequently by comparing these two profits, the difference of profit is TK. 1,617.2 $(41,749.2$ - 40,132), which is $4.03 \%$ more than current profit. So, if the firm follows the new profit maximizing point, the profit of this firm will increase by $4.03 \%$.

\section{CONCLUDING REMARKS}

Profit maximization is the process by which a firm determines the price and output level that provide the maximum profit. To examine the profit maximizing point for dining chair and sofa manufacturing in Navana Furniture Company, Bangladesh, this study uses primary data and simplex linear equation programming by using MATLAB 7.0, C++ software.

The result of the paper demonstrates that if Navana Furniture Company, Bangladesh follows the given new profit maximizing point, under the assumption of equal demand for both products, the profit of the company will increase by $4.03 \%$ for dining chair and sofa manufacturing. The findings of the paper will be helpful for the company management, shareholders as well as other companies to improve their performance.

\section{BIBLIOGRAPHY}

Chvatal, V. Linear programming, W.H. Freeman and Company, New York, 1983.

Dantzig, G.B. Linear Programming and Extensions. Princeton University Press, Princeton, NJ, 1963.

Eppen, D.D., Gould, F.J. and Schmidt, C.P. Introductory Management Science, 2nd ed., PrenticeHall, Englewood Cliffs, N.J., 1987.

Gass, S.I. Linear Programming: Methods and Application. Courier Dover Publications, 2003.

Kornbluth, J.S.H. and Salkin, G.R. The Management of Corporate Financial Assets: Applications of Mathematical Programming Models, Academic Press Ltd., London, 1987.

Navana Furniture, Online [http://www.navanafurniture.com/]

Nering, E.D., Tucker, A.W. Linear Programs and Related Problems. Academic Press, 1992. 